\title{
On Feeling Political: Negotiating (within) Affective Landscapes and Soundscapes ${ }^{1}$
}

\author{
JeAN-Thomas TREMBLAY
}

All of the affective paradoxes of the political in relation to mass demands for social change uttered from the impasse of the present extend from this, cruel optimism's double bind: even with an image of a better good life available to sustain your optimism, it is awkward and it is threatening to detach from what is already not working. (Berlant, Cruel Optimism 263)

She's at a Laurie Anderson show at the Soho Guggenheim. The show is called "Your Fortune, \$1." A white plastic owl is perched on a stool in a darkened corner spewing out a stream of two-bit advice, trenchant commentary, and stray advertising lingo. Its mechanical yet sensuously grainy voice drones on and on, transfixing her on a flood of Hallmark greeting card schlock. But somehow the owl's simple repetitions intensify the ordinary background noise of slogans and cries of alarm, giving it a sensory texture that is at once deadening and weirdly ponderous. (Stewart, Ordinary Affects 114)

\section{Introduction: What Is Feeling Political?}

In September 2011, as the Occupy movement gained momentum, a slogan uproariously infiltrated popular culture: "We Are the 99 Percent." While many have correlated Occupy's genesis with the Adbusters Media Foundation, the origins of the catchphrase that stimulated the movement's growth into a viral phenomenon are blurrier, and have thus become the object of countless journalistic investigations. The narrative to which most have subscribed revolves around "Chris," a New York City activist in his late twenties who, in order to promote the initiation of the Wall Street portion of a protest that would eventually cause a worldwide commotion, launched a Tumblr "microblog" (Weinstein). "We Are the 99 Percent" imposed 
itself as the nucleus of a grassroots campaign as citizens internationally embarked on an autobiographical enterprise, shedding light, by means of their own life story, on the structural inequalities epitomized by the staggering concentration of wealth among the world's top income earners. Beyond the tangible cells, "lifeworlds,"- to borrow from Jürgen Habermas' take on Edmund Husserl's nomenclature — which proliferated in major cities around the globe, the "99 Percent" campaign enabled the Occupy movement to secure a vivid online presence. ${ }^{2}$ The slogan mutated into copious utterances of the personalized and appropriated "I Am the 99 Percent," affirming the existence of a collectivity enacted by a chain of " $I$ 's," and fostering the desire to be political together.

The above case calls attention to the contagious propagation of a sensation that, by virtue of the assertive tone of the slogan from which it stems, intensifies one's sense of belonging to the political realm. The public enunciation of the sentence "I Am the 99 Percent" personalizes the failures of a biased socio-economic infrastructure; indeed, instead of giving rise to a series of mere spokespeople for the disadvantaged, the gesture has allowed participants to incarnate and, thus, feel social inequalities. A digital manifestation of political turmoil with a high potential for the generation of micro-level narratives and story lines, "We Are the 99 Percent" and its derivatives herald the question that nourishes the inquiry put forward in this essay, an exploration which, it will rapidly become patent, moves beyond deliberately "political" speeches, actions, and movements. This question, knotty despite its simplistic structure, reads as What is feeling political?

The project I suggest steers away from some of the efforts previously deployed in an attempt to (re)integrate feelings into political thought, a byproduct of an intensified questioning of the orthodox reason-feelings binary. For instance, in articles such as Martha Nussbaum's 
"Compassion as the Basic Social Emotion," feelings are classified and categorized based on their propensity to encourage the attainment of particular socio-political ends. Through a reading of ancient and modern political thought, Nussbaum constructs a political hermeneutics of sentiments, one that normatively assesses the value of a particular emotion-in this case, compassion - as well as its utility in social life.

Instead of evaluating feelings based on a political grammar, this essay addresses encounters with the political as affective sites and, hence, casts aside discussions of virtue, ethics, and morality. Accordingly, the question What is feeling political? fundamentally calls for an affective hermeneutics of the political. Affect theory constitutes the framework (albeit an ever-fluctuating one) prioritized in this article; more precisely, the question of feeling political is posed in light of Lauren Berlant's descriptive account of noise and ambience with respect to the notions of citizenship and community. "Feeling" and "to feel," in this essay, comprehend awareness, sensation, emotion, intuition, and reaction. ${ }^{3}$ On the other hand, when nominalized, the term "affect" pertains to Gilles Deleuze and Félix Guattari's reading of Baruch Spinoza's "affectus," summarized by translator Brian Massumi as "an ability to affect and be affected. [Affect] is a prepersonal intensity corresponding to the passage from one experiential state of the body to another and implying an augmentation or diminution in that body's capacity to act" (xvi). ${ }^{4}$ A definition of the political that encompasses affects must be an expansive one, incorporating, as Ben Anderson and Berlant argue, both the personal and the impersonal ("Modulating" 165; "The Subject of True Feeling" 61). The political, ergo, exceeds the institutions and infrastructures associated with formal politics; it essentially designates the negotiation of involvement, resistance, association, and even isolation. ${ }^{5}$ 
Before engaging with affect theory, however, I take a significant detour, and perhaps an unexpected one. Political philosopher Simone Weil represents an invaluable asset in elucidating the function of the body in political action. In the subsequent section, I map the environment in which the question of feeling political is situated, proposing an affective political sphere that eludes conventional conceptions of temporality and spatiality. Finally, I focus more specifically on Berlant's work on noise and attachments, and, through Deleuze and Guattari, address the imminent character of feeling political.

\section{Feeling Political as Feeling Right: Simone Weil on Experience and Attention}

Simone Weil's oeuvre constitutes a medium through which the research question considered in this essay can be refined. ${ }^{6}$ Indeed, her emphasis on experience and involvement as means to acquire knowledge of one's social environment accentuates the role of embodiment in political life. Born in Paris in 1909, Simone Weil demonstrated a precocious interest in theory as well as in activism (Saint-Sernin 7-9). She frequently interrupted her teaching engagements, notably to come into contact with the life of factory workers (Saint-Sernin 19-24, 61-64). After a brief sojourn with her relatively bourgeois family in the New York City neighbourhood of Harlem, where she deliberately lived among the poor and refused to consume more food than the individuals who were concurrently living in Nazi-occupied France, Weil moved to England, where she died at the age of 34 (McLellan 266).

Weil's uncanny method of inquiry prompted her to incarnate the ideals she promoted, thus amalgamating theory and practice. This radical emphasis on involvement is perceptible in her critique of Marx's remoteness from praxis in Oppression and Liberty (38-54). Tackling Weil's occupational metamorphoses — as a factory worker, a syndicalist, and a teacher-Attilio 
Danese speaks of a desire to understand reality triggered both by reality itself and by her philosophical research (33). Bernard Saint-Sernin suggests that Weil's reasoning process is very methodical: she experiences a specific condition, extracts its universal element, and establishes a doctrine corroborated by singular experiences and limited facts (4). The logic that sustains Weil's method of investigation conforms to the following sequence: the goal of science, accomplished in the name of a higher purpose, is to acknowledge God's signature in the order of things; because science initiates one to the universe, the experience of science stems from political reflection; and the objective of the art of politics is to remove human beings from oppression, a goal for which a commitment to experience is required (Saint-Sernin 14, 27-28).

Rebecca Rozelle-Stone, citing Robert Coles, observes that as a consequence of Weil's urge for extreme frugality, some of her remarks have been perceived as "prideful, melodramatic, even absurdly self indulgent" (20). Whether it is grotesquely performative or sincerely dedicated, Weil's experience-based approach to philosophy has nonetheless engendered a complex theory of embodiment. Weil's demeanour towards her own body in relation to her vocation as a theorist encapsulates a moderation/immoderation dichotomy. Her core critique of modern society centres on the latter's immoderation and disequilibrium (Rozelle-Stone 18). The extreme moderation she typified (i.e., her scarce consumption of food) could, however, be perceived as an immoderate degree of asceticism. Rozelle-Stone articulates this ostensible paradox as "the tension or disparity between the experience of balance and the reality of imbalance" (20). Ergo, Weil's form of immoderation is antagonistic to the consumption-oriented one that is emblematic of contemporary dwellers. Rozelle-Stone explains, "Immoderate, 'impossible' love is, however, as necessary for loving the good life as natural consumption is necessary for maintaining physical survival" (34). 
Feeling political, in Weil's oeuvre, is thus a twofold phenomenon: a corporeal one, inherent to the experience crucial to political reflection and the analysis of the contemporary world, and a spiritual one, linked with attention. The first dimension of this bimodal construct being directly related to the account of Weil's method of investigation provided in the previous paragraphs, I will promptly jump to the second one. Weil establishes a connection between human collectivities and the souls of the individuals who constitute them. ${ }^{7}$ The respect she bestows on human collectivities, contingent on the latter's continuity, derives from three factors: communities are unique and irreplaceable; they are constantly moving forward into the future; and they are rooted in the past, hence preserving the memory of the dead (Weil, The Need for Roots 8). Due to their ability to fulfil needs, communities guarantee the conditions for each individual's quest for the good. Accessing reality occurs within one's soul, according to an operation that ultimately takes place in a state of solitude (Rozelle-Stone 48; Weil, "Human Personality" 318).

A soul whose needs are satisfied finds itself in an adequate position to hear "the heart which cries out against evil" (Weil, "Human Personality" 316). ${ }^{8}$ This aptness requires a capacity termed "attention," a form of radical openness or awareness (Weil, "Human Personality" 316). Attention, which is exclusive to individuals, is unfocused; it is an acquired disposition that necessitates a high degree of self-mastery in order to hear the sufferer's cry against a background of distracting noise. In her critique of political parties, Weil claims that groups that provide themselves with freedom of expression, "busily seeking, or maintaining [themselves] in, power[,] can discern nothing in these cries except a noise" ("Human Personality" 316). In the letter "Ne recommençons pas la guerre de Troie," Weil assembles an alternative metaphor, trading the soundscape for the landscape; she writes, "It is the cloud of void entities that keeps 
one not only from discerning the data of the problem at hand, but also from sensing that there is a problem to be solved and consequences to be felt" (author's trans. 46). ${ }^{9}$ Attention is a necessary step towards the attainment of the impersonal, or that which is sacred in human beings and includes truth, beauty, and perfection (Weil, "Human Personality" 317-318). Weil summarizes,

Relations between the collectivity and the person should be arranged with the sole purpose of removing whatever is detrimental to the growth and mysterious germination of the impersonal element of in the soul. This means, on the one hand, that for every person there should be enough room, enough freedom to plan the use of one's time, the opportunity to reach ever higher levels of attention, some solitude, some silence. At the same time the person needs warmth, lest it be driven by distress to submerge itself in the collective. ("Human Personality" 321)

A theory that promotes silence and solitude as a precondition for the perception of suffering in society liberates the experience of the political from the unique activity of speech. ${ }^{10}$

In brief, the hypothesis on feeling political extractable from Weil's oeuvre is twodimensional: it relates, first, to a bodily experience critical to political reflection that is exemplified by her radical emphasis on involvement and her discourse on balance, and, second, to a state of extreme attention from whose perspective suffering can be perceived in others. The ideal collectivity generated by Rozelle-Stone's interpretation of Weil's relation to moderation suggests that equilibrated individuals engender a society that relies on some idea of homeostasis; for instance, if everyone exercises his or her capacity for attention, the heart's cry against evil is heard. While Weil is right to claim that human beings are not (or no longer) organisms of balance, I argue that this phenomenon is not a sign of idleness or apathy as much as it is, at least in the current context, a non-negotiable product of neoliberal society.

Weil's theoretical scheme presumes that there exists a right way to act in order to be able to properly feel political. How should one classify, then, feeling political when it emerges unintentionally or unconsciously? When "We Are the 99 Percent" becomes "I Am the 99 
Percent," or when the pain of others is increasingly felt and shared as mere noise grows into a communally-uttered hymn? When people's race, gender, or sexual orientation causes them to become objects of public contention? When, in short, individuals are compelled to negotiate the terms of their involvement, resistance, association, and isolation vis-à-vis groups, objects, and ideas?

The inescapable normativity of a Weilian definition of feeling political does not shed light on particular flaws in her theory; Weil herself recognized the standard-setting character of her project. Instead, this cul-de-sac underlines the dissonance between a political theory intended to provide new bases for a constitution on one hand, and my attempt to establish an affective hermeneutics of the political on the other. ${ }^{11}$ Weil may offer a sophisticated depiction of the political experience, one that is incarnated and felt, but the question of feeling political warrants that the accent be placed on the descriptive rather than the normative. ${ }^{12}$ By abandoning Weil, I emphasize that the research question that motivates my exploration is not How to feel political? but rather, again, What is feeling political? My inquiry does not seek to locate the right way to feel political; it pertains to the inevitability of feeling as such. Furthermore, it aspires to conceptualize feeling political as a phenomenon that evades the Cartesian body/mind division perceptible in my account of Weil's work.

\section{III.Spacing the Political: Sphere, Atmosphere, Rhizome, Assemblage}

A less purposefully normative account of the political experience which presumes the potential for feeling political to spring from of the interstices of formal politics entails a political sphere characterized by the circulation of affects. ${ }^{13}$ As per the definition of the political proposed in the introduction, the political sphere is the locale in which the negotiation of involvement, 
resistance, association, and isolation occurs, in conscious and unconscious ways. Eve Kosofsky Sedgwick's definition of affects underlines their flexibility as well as their tendency to append themselves to objects, individuals, or ideas, influencing their intensity and their capacity to trigger emotional responses. She writes, "Affects can be, and are, attached to things, people, ideas, sensations, relations, activities, ambitions, institutions, and any number of other things, including other affects" (19). Kathleen Stewart, in her literary examination of everyday affects, lays stress on the motion and the non-linearity of this concept.

Ordinary affects are public feelings that begin and end in broad circulation, but they're also the stuff that seemingly intimate lives are made of. They give circuits and flows the forms of a life. They can be experienced as a pleasure and a shock, as an empty pause or a dragging undertow, as a sensibility that snaps into place or a profound disorientation. They can be funny, perturbing, or traumatic. Rooted not in fixed conditions of possibility but in the actual lines of potential that a something coming together calls to mind and sets in motion, they can be seen as both the pressure points of events or banalities suffered and the trajectories that forces might take if they were to go unchecked. (2)

The boundaries of affective spaces, the values they encompass and project, and the trajectories that sound and light follow within their parameters are some examples of attributes that render each unique. Even the quotidian-or, as per Stewart, especially the quotidian-detains the potential for those who inhabit it to feel political. The prevalent disregard for this postulation may be attributed to the idea that unlike institutions, within whose confines activities are highly ceremonial, the mode of ritualization that tends to calibrate feeling political in the mundane has been rationalized and integrated to the extent that its political dimension is generally overlooked.

Spacing the political realm as an indeterminate number of flexible and overlapping affective sites presents certain similarities with Ben Anderson's research on affective atmospheres. Affective atmospheres, as the author argues in the article of the same name, hold a series of opposites — presence/absence, materiality/ideality, definite/indefinite, and singularity/generality- 
in a relation of tension (77). Anderson portrays an ambiguous affective sphere characterized by a constant state of flux. He associates atmospheres with epochs, societies, rooms, landscapes, couples, and artwork, and adds that they "are singular affective qualities that emanate from but exceed the assembling of bodies" (77-78). His assertion that atmospheres "are impersonal in that they belong to collective situations and yet can be felt as intensely personal," juxtaposed with the previously established affective definition of the political as encompassing both the personal and the impersonal, affirms the pertinence of Anderson's understanding of atmospheres in mapping the circulation of affects that forms the phenomenon of feeling political (81).

The political sphere I propose is, by Deleuze and Guattari's definition, a "rhizomatic" capacity (6). The political is, hence, a capacity (negotiation, or a fundamental impulse to affect and be affected) that produces itself as a capacity (a realm, albeit not simply a geographical one). The two authors describe the botanical rhizome at the origin of the homonymous philosophical concept as follows: "The rhizome itself assumes very diverse forms, from ramified surface extension in all directions to concretion into bulbs and tubers" (7). A rhizomatic conception of the locale in which feeling political occurs deconstructs definite claims of predetermined directionality, both spatially and temporally. It also permits the generation of a political sphere whose circumference remains fluid. This rhizomatic political sphere, in which individuals and groups (as well as other biological organisms, ideas, and objects) constitute affective assemblages, exists beyond the formal political sphere that materializes as a rigid institutional structure. Deleuze and Guattari clarify the concept of assemblage as "precisely this increase in the dimensions of a multiplicity that necessarily changes in nature as it expands its connections. There are no points or positions in a rhizome, such as those found in a structure, tree, or root. There are only lines" (8). The affective atmosphere of the political realm is territorialized into 
shared experiences of affects; likewise, the "lines of flight" that traverse affective atmospheres and surge out of them ensure the affective contagion that prevents said atmospheres from becoming hermetic (4).

While a political sphere understood as a rhizomatic affective atmosphere is characterized by the circulation of affects between matter, human and nonhuman alike, it should not be believed that commonly-felt affects necessarily lead to homogenous feelings. What is binding for humans, I suggest, is not a specific feeling regarding the political, but the way in which the phenomenon of feeling political triggers personal and collective narratives. Inclinations, predispositions, and orientations mediate the affects universally felt as variations of intensity, producing responses in the form of opinions, positions, and additional orientations. Sara Ahmed's work on orientation in the realm of affect theory insinuates this idea. Ahmed holds that the promise of happiness directs individuals towards certain objects ("Sociable Happiness" 10; "Happy Objects" 29). Concurrently, individuals direct happiness towards these objects ("Sociable Happiness" 10). The intentionality implied in her claim that "happiness is an orientation towards the objects we come into contact with" indicates that her interest in affects (i.e., contact) communicates a certain phenomenological undertone (i.e., orientation, directionality) (“Sociable Happiness" 10). Expanding Ahmed's proposal, I suggest that feelings (at large) are an orientation towards the objects (at large, too) humans come into contact with. Feeling political, then, is intimately connected with the negotiation of one's orientation towards other people, objects, and ideas in the political sphere; its manifestation ranges from radical resistance to radical passivity (which are not polar opposites on a continuum, considering that rhizomes rebuff the notion of spatiotemporal systemization). The very existence of Ahmed's previous work on queer phenomenology substantiates my claim that the circulation of affects in 
the spheres people inhabit does not necessarily produce sheer uniformity; indeed, particular orientations may constitute an entranceway towards modes of feeling political characterized by alternative forms of belonging, or by an alienation from the majority. ${ }^{14}$

\section{IV.On Feeling Political: Noise, Attachment, Becoming}

Having determined the scope of my investigation and the realm associated with the phenomenon at hand, I now wish to concentrate on the mechanics at play in feeling political. How do orientations reveal themselves within and across affective atmospheres? Through this reformulation of my research question, the notion of inevitability disseminated throughout the previous sections of this essay will be formally unravelled. Before attending to Berlant's insight on the matter, it is essential to note that the way she phrases her definition of the political somewhat diverges from the one presented in this essay. Berlant understands politics as a space of antagonisms (e.g. in relation to race, class, gender, and sexuality), and the political as that which conveys or actualizes the desire for sociality, solidarity, fantasy, or project (Cruel Optimism 225-226, 249). Berlant's "political" is, thus, desirable—or, at least, desired. By defining the political as the negotiation of various forms of membership, I leave the door open to the idea that this mediation is often aimed at ideals of sociality and solidarity, but maintain that whatever results it engenders, said mediation occurs endlessly. Chantal Mouffe argues that "every order is political and based on some form of exclusion" (18). I contend that the motivation behind said orders is not always some idea of sociality or solidarity; the promise of power, fear, or disgust, for instance, may be impulses. ${ }^{15}$ 
Initiating her consideration of noise, Berlant offers a detailed reading of George W. Bush's declaration, "Somehow you just got to go over the heads of the filter and speak directly to the people" (Cruel Optimism 223). She argues,

Bush's wish to skirt the filter points to something profound in the desire for the political. He wants to transmit not the message, but the noise. He wants the public to feel the funk, the live intensities and desires that make messages affectively immediate, seductive and binding. In his head a public's binding to the political is best achieved neither by policy nor ideology but the affect of feeling political together, an affect of having communicated true feeling without the distancing mediation of speech. The transmission of noise performs political relations as sustaining intimate relation, without which great dramas of betrayal are felt and staged ... Uncertainty is the material that Bush wished to bracket. His desire for a politics of ambient noise, prepositional transmission, and intuitive reciprocity sought to displace the filtered story of instability and contradiction from the centre of sociality. He also wishfully banished self-reflexive, cultivated opinion and judgment from their central public-sphere function ... The contemporary filtered or mediated political sphere in the United States transmits news $24 / 7$ from a new ordinary created by crisis, in which life seems reduced to discussions about tactics for survival and who is to blame. The filter tells you that the public has entered a historical situation whose contours it does not know. (Cruel Optimism 224-5)

In the aforementioned passage, Berlant powerfully conveys the immense influence of the desire for commonly-felt variations of intensity on the determination of people's orientations in the political sphere. If the repeated pulsation of Bush's humming pushes people to mistake their allegiance to a suppressive rhetoric for something meaningfully or genuinely public, the "We Are the 99 Percent"/“I Am the 99 Percent" case chronicled in the introduction of this essay illustrates how the communal production of noise can also indicate a desire for alternative, less detrimental, and more lucid modes of sociality. Whether or not the "99 Percent" campaign has reached its target is open to debate. The theoretical framework I prioritize would make an authoritative claim on this issue futile; what is detectable in both cases at hand, though, is a common desire for ambience. 
Berlant's analysis of Bush's address signals that the modalities of affective soundscapes are partly influenced by the dissemination of political rhetoric in the form of noise. Supplementary examples include the 2011 platform of the Conservative Party of Canada, which comprises more than 60 instances of the expression "to create jobs"/“creating jobs"/“job creation"/“source of jobs." These terms form a rhythmic motif that multi-directionally voyages through a variety of vehicles, audiovisual or otherwise. They vibrate and pulsate, and impel people to vibrate and pulsate as well. Moreover, the reduction of political speeches to Twitterfriendly taglines of 140 characters or less is an example of how the digital as a constituent of affective atmospheres regulates, disciplines, and systemizes speech into noise that is easily propagated.

The nuances of Berlant's examination of noise are especially visible in light of Weil's notion of attentive silence. Berlant writes:

Performative silence is therefore not simply political speech that might as well be spoken. It is also really silence, by which I mean noise: that circulating, transpersonal, permeating, viscerally connective affective atmosphere that feels as though it has escaped "the filter" to indicate, for good or for ill, a sensorium for a potential social world now lived as collective affect, or a revitalized political one. (Cruel Optimism 231)

Berlant, in contrast with Weil, does not affirm the virtue of silence as much as she describes how communal performances characterized by silence have allowed people to constitute affective atmospheres that offer an interruption from the buzzing noise of regimentation. Noises are inescapably heard and felt by people who, in turn, adopt (political) orientations towards them, influencing the vectors according to which affects voyage in atmospheres.

It would be erroneous to unequivocally claim that affects annihilate the capacity for cognition. Rather, my intention is to expose the mechanisms according to which affects heavily impact reasoning. Gerda Roelvink contends that the anti-globalization movement has adopted a 
politics of affect; instead of disputing neoliberal ideology, it has distorted habits of thinking about neoliberalism (111). Affects, then, hold a certain pedagogical function; furthermore, their manipulation leads to a variation of a group's capacity to act (111). The noise of Bush's discourse engenders a pulsation that dismisses alternative ways of thinking about one's social position. On the other hand, the "We Are the 99 Percent" campaign unveils the workings of affective noise in order to promote a more hostile orientation towards the dominant rhetoric of the state/corporate apparatus. Similarly, the "Rally to Restore Sanity and/or Fear," which took place on October 30, 2010, was an opportunity, according to American comedian Jon Stewart, for "the 70-80 percent of Americans who try to solve the country's problems rationally [to] be heard above the more vocal and highly visual 15-20 percent who "control the conversation"” (AFP). ${ }^{16}$ The initiative, piloted by Stewart and his colleague Stephen Colbert, in-character as a right-wing guru, orchestrated the event as a response to conservative pundit Glenn Beck's "Restoring Honor" rally (AFP). The satirical rendition of political antagonisms proposed by Stewart and Colbert brilliantly underlines the absurdity of the generation of fear-as-noise. Different attitudes, positions, and orientations towards noise or affects engender dissimilar ways of feeling political. Whether one experiences a soothing impression of stability and safety or the vertigo of contestation, one feels something, and in a deeply political manner.

Instead of indulging in the Habermasian narrative of the loss of the public sphere, Berlant concerns herself with the present; she announces that there currently is no public sphere. Abiding by this logic, not only the future, but also the very present we dwell in constitutes a site of uncertainty. This idea is reflected in Occupy's discourse, broached in the introduction. The slogan, "We Are the 99 Percent" does not project individuals or groups into some glorified, more bearable future so much as it affirms the historicity of an affective present. Berlant writes, 
Public spheres are always affect worlds, worlds to which people are bound, when they are, by affective projections of constantly negotiated common interestedness. But an intimate public is more specific. In an intimate public one senses that matters of survival are at stake and that collective mediation through narration and audition might provide some routes out of the impasse and the struggle of the present. (Cruel Optimism 226)

The many utterances of "I Am the 99 Percent" animate an intimate public that comprises every individual who conjugates the movement's tagline in the first-person singular and, of course, in the present tense. Whether or not this negation of the ambient noise generates a more livable present is, once again, debatable, but the urge for a shared feeling exemplified by this initiative is quite conspicuous. "I Am the 99 Percent" belongs to the vernacular; it highlights the matter that carries a certain potential for political revolt in the quotidian, while attesting that what makes said matter (i.e., social inequalities) worthy of anger is specifically its unexceptional character. ${ }^{17}$

Berlant brings to the fore the notion of attachment in her elucidation of the desire for the political. In line with my slightly differing definition of the political, Berlant's enterprise amounts to pondering the motives behind one's orientations in the negotiation of the terms of his or her involvement, resistance, association, and isolation. Berlant argues that "an intimate attachment to the political can amount to a relation of cruel optimism" (Cruel Optimism 227). The pivotal concept in her book of the same name, cruel optimism arises when one desires an object that is, in actuality, detrimental to one's flourishing (1-2). Here, the term "object" is understood loosely; it can refer to an idea (e.g. belonging, intimacy), a physical thing (e.g. food), or even a ritual (e.g. marriage). Berlant writes,

How and why does this attachment persist? Is it out of habit? Is it in hopes of the potentiality embedded in the political as such? Or, from a stance of critical engagement, an investment in the possibility of its repair? The exhausting repetition of the politically depressed position that seeps repair of what may be constitutively broken can eventually split the activity of optimism from expectation and demand. Maintaining that split enables one to sustain one's attachment to the political as such and to one's sense of membership in the idea of the polity, which is a virtual — but sensual, not abstract—space 
of the commons. And so, detaching from it could induce many potential losses along with new freedoms ... Add to this the possibility that "the political" as we know it in mass democracy requires such a splitting of attachment and expectation. Splitting off political optimism from the way things are can sustain many kinds of the cruelest optimism. (Cruel Optimism 227-228)

Sensual attachments to people, objects, and ideas enforce, reinforce, and alter one's orientations towards the polity; these attachments arise as a corollary of affectivity, or the fundamental impulse for negotiation, and further influence this phenomenon.

Psychoanalysis, particularly the work of John Bowlby, offers constructive insight in regard to attachment and its role in social life. In A Secure Base, Bowlby presents a form of attachment theory that contrasts with the model based on which the child's personal relationship (i.e., dependency) with the mother comes as a secondary drive determined by the fact that the mother is the child's primary food provider (24-25). In Bowlby's alternative model, attachment is defined as a form of behaviour resulting from the attainment and preservation of proximity with other people more capable to deal with the world (25-27). Attachment, therefore, is not exclusive to children; it extends to teenagers and adults, and constitutes "a fundamental form of behaviour with its own internal motivation distinct from feeding and sex, and of no less importance for survival" (27). Bowlby's work is in no way entirely consistent with the ideas expressed by the affect theorists included in this essay; not even Berlant, whose book Cruel Optimism stresses the role of attachment(s) in social behaviour, mentions Bowlby in her bibliography. However, applying the concepts conveyed in A Secure Base to the political sphere is helpful in explaining how attachments to the individuals, ideas, and objects that form social environments may be affectively perceived as essential to survival, even if they are not indispensable to the physical preservation of the body. Attachments draw a vector between one's body and a person, idea, or object with which he or she becomes emotionally invested. Likewise, 
the variation of intensity of attachments provokes corporally felt reactions (e.g. lack, loss) and prompts human beings to seek their restoration.

If Bowlby's discussion of attachment is a pertinent addition to Berlant's theory regarding the desire for the political, Deleuze and Guattari enable me to highlight the humanist frame within which Berlant's theory is applicable. Deleuze and Guattari's emphasis on the affectivity of all matter, by whose means things are attracted to things (e.g. atom to atom), is, in part, relatable to my assertion that the magnetism of biological organisms, ideas, and objects calls for a persistent mediation (45). While all things are affective, the explicit narration of the negotiation of affectivity through which the political is enacted is precisely what distinguishes human matter from nonhuman matter. The formation of one's "social self" visible in the phrase "I Am the 99 Percent," essentially an affective construction, is a typical way in which the negotiation at the heart of the phenomenon of feeling political is recounted by humans as a narrative.

This essay has situated the political in the realm of the inescapable. The "always-already" character of political experience correlates with the imminence indissociable from Deleuze and Guattari's writings on "becoming." Inspired by these two thinkers, I argue that the "alwaysalready" trait of matter's encounter with the political entails that matter is "becoming-political." Deleuze and Guattari claim,

[S]omething else entirely is going on: not imitation at all but a capture of code, surplus value of code, an increase in valence, a veritable becoming, a becoming-wasp of the orchid and a becoming-orchid of the wasp. Each of these becomings brings about the deterritorialization of one term and the reterritorialization of the other; the two becomings interlink and form relays in a circulation of intensities pushing the deterritorialization ever further. There is neither imitation nor resemblance, only an exploding of two heterogeneous series on the line of flight composed by a common rhizome that can no longer be attributed to or subjugated by anything signifying. (34) 
All matter, considering that it is affective, is always already negotiating the terms of its involvement, resistance, association, and isolation in relation to other matter. All matter is, then, always already becoming-political. It appears impossible to prove that feeling political (which I summarize as a sense or an awareness of the changes of intensity provoked by the circulation of affects between different clusters of matter) is a typically human occurrence. What is human, though, is the way in which feeling political (as a verb, a process) is concretized into specific feelings of the political (as a noun, a state) depending on preexistent (albeit incessantly alterable) orientations (e.g. sentimentality). ${ }^{18}$ Feeling political does not manifest itself as either extremity of a binary that locates acquiescence to tyrannical political noise on one end, and active resistance on the other. On the contrary, the rhizomatic character of becoming-political suggests endless possibilities regarding the ways we change states and the particular feelings such transformations trigger. Considering that feeling political defines existence, the question that underpins this essay is, ultimately, an ontological one: to be is to be affective. It is to be always already negotiating the terms of one's attachment or detachment in relation to other matter. It is, in short, to become-political and to sense the changes of intensities thusly implied.

\section{Conclusion: Staging Noise}

Olivier Choinière's dialogue-free play Chante avec moi typifies many of the ideas collected in this essay. ${ }^{19}$ In an attempt to highlight what Melissa Gregg describes as "the potential for affects to be generated, disseminated and caught through a textual voice," I propose to conclude my argument with a close reading of this cultural object (9). In the first segment of Chante avec moi, more than 50 performers dressed as civilians progressively converge towards a public area and sing a twelve-part song. The vigour of the noise they engender amplifies as the 
cast organizes itself as collectivity. The inaugural act culminates with the arrival on stage of a real-life celebrity, eliciting a general sense of euphoria. In the second portion of the show, all characters become hyperbolic selves as they perform an inflated rendition of the first act. The exhilaration suddenly evaporates when the guest celebrity whose return the performers eagerly anticipate fails to join them to sing the concluding passage of the song. In the final act, which is much briefer, the piece is sung at an accelerating pace. The cast members, assembled as a block, display emotionless faces. They sing and, one by one, collapse, motionless.

Choinière's work superbly articulates the affective charge of noise as it voyages through atmospheres, coincidentally illustrating the interplay between affects and orientations. It also constitutes an ideal canvas onto which the notion of feeling political can be applied. What comes into sight as a method of empowerment through a communal act of production is subverted by the sense of approval provided by the mythologized figure of the celebrity. The activity of uniting to sing the anthem is, hence, overshadowed by the promise of validation that the cast assumes will occur again towards the end of the second rendition of the song. Despite realizing that said validation does not arise, the performers fervently maintain their attachment to the idea that betrayed them until their "cruel optimism" prompts their death. Affective vectors are materialized and spatialized in Choinière's mise-en-scène, and so is the complex network of attachments at play in the negotiation of each cast member's social self. If the specific feelings that the characters experience — and affectively communicate to the audience-fluctuate throughout the play, said characters' negotiation of the notions of involvement, resistance, association, and isolation vis-à-vis objects, ideas, and each other is ceaseless. Specific political feelings, in Chante avec moi, include a communal sense of empowerment, anticipation (less communal, given that instead of connecting people together, affective vectors link each 
individual to the ideas symbolized by the motif of the celebrity), and a lonely process of extinction. The pathetic tragedy of Chante avec moi's ending, evidence that feeling political does not always feel right, parallels Berlant's conclusion that "even with an image of a better good life available to sustain your optimism, it is awkward and it is threatening to detach from what is already not working" (Cruel Optimism 263).

The presentation of Chante avec moi in conventional performance spaces (Espace Libre, in Montreal, and the National Arts Centre, in Ottawa) conveys a desire to reinvest traditional artistic institutions. Instead of mimicking a standard narrative of opposition or resistance (i.e., the subjection of a normative pulsation to a marginal one), the play employs a bewitching pop song in order to viciously interrogate the very mechanics — and the politics — of space and noise within the theatre as a point of convergence. Thereby, the performances of Chante avec moi enact, despite a distinct tone and purpose, an atmosphere similar to that the Occupy movement, one based on a wish to examine the configuration of public areas and the motion they allow as a means to deconstruct the formation of discourse in society. While the Occupy movement roots its collective affirmation in an elementary, 99\%-versus-1\% mythology, though, Chante avec moi conveys with a greater deal of complexity the viral transmission of orientations in the neoliberal present.

A recent restaging of Chante avec moi concurred with the pinnacle of the 2012 student movement in Montreal. The limited engagement began only days after the ratification by the National Assembly of Quebec of "An Act to enable students to receive instruction from the postsecondary institutions they attend" (commonly referred to as Bill 78), which has imposed limitations on Quebec citizens' freedom of assembly and protest (CBC News). One of the pillars of this emergency law is the requirement for all contingents of 50 individuals or more to inform 
their local police service of the itinerary of a planned demonstration at least eight hours in advance (CBC News). Conscious of the fact that Chante avec moi brings together more than 50 people in what aesthetically resembles a demonstration, Choinière resolved to communicate a detailed account of the gestures the performers would make to the Montreal Police Service (Donnelly). By emphasizing the performative nature of the context in which his play was presented and letting it contaminate the piece itself, Choinière displayed not only the repressive devices that regulate (political) orientations in today's society, but also the passivity with which control and governmentality are generally welcomed. While Choinière's deconstruction of collective affects compels the audience members to undertake a reflection regarding their orientation within the performance space, it enables them as citizens by repudiating preconceived ideas regarding what the outcome of this reflection should be.

In the spirit of the subject matter at hand, this essay's intensity has persistently oscillated, accumulating diversions and digressions in search of coherence, correspondence, and stability. Gregg, alluding to Teresa Brennan's work, proposes that "the transmission of affect has yet to be adequately theorized because Western modes of perception are particularly challenged by the idea that we may not be in control of our feelings, moods and actions as individuals" (9). The prototypal nature of my enterprise is no stranger to affect theory's own concern with indefinite entities and the intricacy of the bonds they nurture. This essay carries an affective potential that is rendered especially obvious by my concern with the narrativization of affect. This piece, therefore, does not aim to objectify the phenomenon of the circulation of affects, nor is it intended to be felt solely as an open set of varying intensities whose rhizomatic nature may induce an indeterminate number of orientations. Rather, inspired as much by Gregg's acutely self-aware scholarly writings as by Choinière's highly performative theatre, I have aspired to 
work towards a form of affective cognition that ignites a debate on the question of feeling political without reducing the ways in which we feel as such to a set of normative standards.

By theorizing feeling political as inherent to a negotiation that is always already occurring, I imply that not only sentiments customarily seen as counter-political (e.g. tranquillity), but also what many fathom as an absence of sentiments (e.g. apathy) constitute ways of feeling political that have limitless repercussions. Whether noise animates us, fills us with indignation, or puts us to sleep, the inescapable negotiation of those possibilities triggers affective responses and indexes the intensity with which we will, in turn, affect the atmospheres in which we dwell.

\section{Notes}

${ }^{1}$ I wish to thank Sophie Bourgault and Julian Gill-Peterson for their insightful comments on previous versions of this essay.

${ }^{2}$ Occupy cells have promoted a mode of communication oriented towards the fulfillment of a collectivity's well-being, one that is incongruous with strategic rationality (i.e., a form of rationality that instrumentalizes communication for the attainment of ends that are embedded in a logic of profitable production). These milieus, thus, can be conceptualized as lifeworlds (i.e., bastions of intersubjectivity) in which the public sphere is freed from mediation by a system where corporate, military, and governmental interests coincide. See Habermas.

${ }^{3}$ While I do not address each denotation of "feeling" or "to feel" extensively, my employment of this multifaceted notion merges awareness, sensation, emotion, intuition, and reaction. Moreover, I use the term "awareness" rather than "consciousness" because of the latter's habitual association, especially in modern political thought, with cognition, or enlightened reason.

${ }^{4}$ Gregory J. Seigworth and Melissa Gregg, in "An Inventory of Shimmers," the introduction to their Affect Theory Reader, highlight Sylvan Tomkins' contribution to the inception of affect theory. The authors target Eve Kosofsky Sedgwick and Adam Frank's recuperation of Tomkins' neurological perspective on affect as well as Massumi's embracement of "Gilles Deleuze's Spinozist ethology of bodily capacities" as watersheds in the short history of affect theory (5). They write, "There is ... a certain sense of reverse flow between these lines of inquiry - a certain inside-out/outside-in difference in directionality: affect as the prime 'interest' motivator that comes to put the drive in bodily drives (Tomkins); affect as an entire, vital, and modulating field 
of myriad becomings across human and nonhuman (Deleuze)" (6). While I do make a few references to Sedgwick in this essay, I have prioritized the second "strand" of affect theory catalogued by Seigworth and Gregg because Tomkins' highly codified list of affects contradicts my endeavour to avoid restrictive conceptual categories in defining the phenomenon of feeling political. This decision, I believe, is consonant with Seigworth and Gregg's own definition of affect as "persistent proof of a body's never less than ongoing immersion in and among the world's obstinacies and rhythms, its refusals as much as its invitations" (1).

5 Politics and "the political" are closely interconnected. Chantal Mouffe, who concerns herself with "the current practices of democratic politics and ... therefore [locates her inquiry] at the 'ontic' level," argues that "it is the lack of understanding of 'the political' in its ontological dimension which is at the origin of our current incapacity to think in a political way [at the 'ontic' level]"' (9).

${ }^{6}$ To start with, it should be established that Weil is not an antipolitical thinker; while she condemns some of the practices inherent to politics as we know it (e.g. political parties, or the primacy of rights over obligations), she does not establish a case against the political, which is ultimately what this essay concerns itself with. Order, obedience, equality, punishment (disciplinary and penal), and responsibility-some of the essential needs of the soul enumerated by Weil - are indissociable from the community (The Need for Roots 10-40). The collectivity is, thus, not inherently wrong, but it must be seen as the result of operations "performed by a mind in a state of solitude" (Weil, "Human Personality" 320).

${ }^{7}$ Collectivities do not only address the needs of the soul; they should also fulfill the needs of the body (Weil, The Need for Roots 7).

${ }^{8}$ By enabling us to hear "the heart which cries out against evil," attention makes our encounter with other people's longing for the good very intimate; it is felt (Weil, "Human Personality" 316).

9 “C'est le nuage des entités vides qui empêche non seulement d'apercevoir les données du problème, mais même de sentir qu'il y a un problème à résoudre et une facture à subir" (Weil, "Ne recommençons pas la guerre de Troie" 46).

${ }^{10}$ Weil does not abandon speech, but I propose that the way she defines the experience of the political suggests that this phenomenon transcends verbal expression.

${ }^{11}$ In the preface to The Need for Roots, T.S. Eliot writes, "This book was written during the last year or so of Simone Weil's life, during her employment at French Headquarters in London; and it issues, I understand, from memoranda which she submitted in connection with the polity to be pursued after the Liberation" (Weil xiii).

${ }^{12}$ It is not my contention that a purely descriptive account of feeling political is even possible; however, I maintain that a theorist who, like Simone Weil, establishes a series of steps that make 
feeling political and its generation of desired outcomes possible is at odds with my project to avoid normative prescriptions.

13 I refrain from overemphasizing the term "descriptive" because my own account of affect necessarily entangles itself with the affectivity I wish to capture. The interplay between language and affect is too significant for me to dismiss the subjectivity (and the performativity) inherent to my enterprise. I discuss this further in the Conclusion.

14 For Sara Ahmed's work on queer phenomenology, see "Orientations: Toward a Queer Phenomenology," and Queer Phenomenology: Orientations, Objects, Others.

${ }^{15}$ In Ugly Feelings, Sianne Ngai claims that disgust constitutes a significant variable in political commitment. She writes, "[D]isgust does not so much solve the dilemma of social powerlessness as diagnose it powerfully. But while all of the negative affects we have discussed call attention to this problem, the poetics of disgust seems to have drawn us closer to the domain of political theory, perhaps even of political commitment, than the others. In its intense and unambivalent negativity, disgust thus seems to represent an outer limit or threshold of what I have called ugly feelings, preparing us for more instrumental or politically efficacious emotions. It therefore brings us to the edge of this project on the aesthetics of minor affects, marking the furthest it can go" (353-354).

${ }^{16}$ Quite ironically, Stewart's employment of the term "rationally" suggests that he is proposing that enlightened rationality can annihilate noise. Such a stance would repudiate the work of affect in his rally.

${ }^{17}$ Berlant theorizes the situation described as follows: "[M] ost of social life happens in such modes of lower case drama, as we follow out pulsations of habituated patterning that make possible getting through the day (the relationships, the job, the life) while the brain chatters on, assessing things in focused and unfocused ways" ("The Subject of True Feeling" 6).

18 John Protevi suggests the concept of "bodies politic" to designate "cognitive agents that actively make sense of situations: they constitute significations by establishing value for themselves, and they adopt an orientation or direction of action. This cognition is co-constituted with affective openness to that situation; affect is concretely the imbrication of the social and somatic, tracking the ways our bodies change in relation to the changing situations in which they find themselves" (33).

${ }^{19}$ For additional information on Choinière's methodology and the underlying themes of his work, see my text "L'aliénation du merveilleux." 


\section{Works Cited}

AFP. "US Comics Unveil Dueling DC Political Rallies.” Agence France Presse. 2010. Web. 10 March 2012.

Ahmed, Sara. "Happy Objects." The Affect Theory Reader. Eds. Melissa Gregg and Gregory J. Seigworth. Durham: Duke University Press, 2010. 29-51.

- "Orientations: Toward a Queer Phenomenology." GLQ: A Journal of Lesbian and Gay Studies 12, no. 4 (2006): 543-574.

- Queer Phenomenology: Orientations, Objects, Others. Durham: Duke University Press, 2006.

. "Sociable Happiness." Emotion, Space and Society 1, no. 1 (2008): 10-13.

Anderson, Ben. “Affective Atmospheres." Emotion, Space and Society 2, no. 2 (2009): 77-81.

- "Modulating the Excess of Affect." The Affect Theory Reader. Eds. Melissa Gregg and Gregory J. Seigworth. Durham: Duke University Press, 2010. 161-185.

Berlant, Lauren. Cruel Optimism. Durham: Duke University Press, 2011.

- "The Subject of True Feeling: Pain, Privacy, and Politics." Cultural Studies and Political Theory. Ed. Jodi Dean. Ithaca: Cornell University Press, 2000. 42-62.

Bowlby, John. A Secure Base. New York: Basic Books, 1988.

CBC News. "Quebec Human Rights Commission Slams Bill 78." CBC. 2012. Web. 19 July 2012.

Conservative Party of Canada. "Here for Canada: Stephen Harper's Low-Tax Plan for Jobs and Economic Growth." Conservative Party of Canada. 2011. Web. 10 March 2012.

Danese, Attilio. "Recherche du moindre mal: La critique weilienne du politique." Simone Weil: Action et contemplation. Ed. Emmanuel Gabellieri and Maria Clara Lucchetti Bingemer. Paris: L'Harmattan, 2008. 33-60.

Deleuze, Gilles and Guattari, Félix. A Thousand Plateaus: Capitalism and Schizophrenia. Trans. Brian Massumi. Minneapolis and London: University of Minnesota Press, 1987.

Donnelly, Pat. "Festival Trans-Amériques: The Debacle Sees Actor, Director Swap Roles." The Gazette. 2012. Web. 28 July 2012.

Gregg, Melissa. Cultural Studies' Affective Voices. New York: Palgrave Macmillan, 2006. 1-25. 
Habermas, Jürgen. The Theory of Communicative Action: Volume Two: Lifeworld and System, A Critique of Functionalist Reason. Trans. Thomas McCarthy. Boston: Beacon Press, 1987.

McLellan, David. Utopian Pessimist: The Life and Thought of Simone Weil. New York: Poseidon Press, 1990.

Mouffe, Chantal. On the Political: Thinking in Action. New York: Routledge, 2005.

Ngai, Sianne. Ugly Feelings. Cambridge: Harvard University Press, 2006.

Nussbaum, Martha. "Compassion as the Basic Social Emotion." Social Philosophy and Policy 13, no. 1 (1996): 27-58.

Protevi, John. Political Affect: Connecting the Social and the Somatic. Minneapolis: University of Minnesota Press, 2009.

Roelvink, Gerda. "Collective Action and the Politics of Affect." Emotion, Space and Society 3, no. 2 (2010): 111-118.

Rozelle-Stone, A. Rebecca. "Simone Weil and the Ethic of (Im)moderation." The Relevance of the Radical: Simone Weil 100 Years Later. Ed. A. Rebecca Rozelle-Stone and Lucian Stone. London: Continuuum, 2010. 18-37.

Saint-Sernin, Bertrand. "L'action politique selon Simone Weil, Deuxième édition." Académie des sciences morales et politiques. 2008. Web. 24 Feb. 2012.

Sedgwick, Eve Kosofsky. Touching Feeling: Affect, Pedagogy, Performativity. Durham: Duke University Press, 2003.

Seigworth, Gregory J. and Gregg, Melissa. "An Inventory of Shimmers." The Affect Theory Reader. Eds. Melissa Gregg and Gregory J. Seigworth. Durham: Duke University Press, 2010. 125.

Stewart, Kathleen. Ordinary Affects. Durham: Duke University Press, 2007.

Tremblay, Jean-Thomas. “L’aliénation du merveilleux.” Voir. 2011. Web. 24 Feb. 2012.

Weil, Simone. "Human Personality." Simone Weil-Selected Essays. London: Oxford University Press, 1962. 313-339.

—. "Ne recommençons pas la guerre de Troie." Les classiques des sciences sociales. 2003. Web. 24 Feb. 2012. 
The Needs for Roots: Prelude to a Declaration of Duties Towards Mankind. New York: Routledge, 1996.

Weinstein, Adam. "We Are the 99 Percent' Creator Revealed." Mother Jones. 2011. Web. 24 Feb. 2012. 